\title{
Cytological Investigation of Resistance to Leptosphaeria maculans Conferred to Brassica napus by Introgressions Originating from B. juncea or B. nigra B Genome
}

\author{
S. Roussel, M. Nicole, F. Lopez, M. Renard, A. M. Chèvre, and H. Brun
}

First and sixth authors: Station de Pathologie Végétale; and fourth and fifth authors: Station d'Amélioration des Plantes, INRA, BP29, 35653

Le Rheu Cedex, France; and second and third authors: Genetrop Laboratoire de Phytopathologie, IRD, BP 5045, 34032 Montpellier, France.

Accepted for publication 16 August 1999.

\begin{abstract}
Roussel, S., Nicole, M., Lopez, F., Renard, M., Chèvre, A. M., and Brun, H. 1999. Cytological investigation of resistance to Leptosphaeria maculans conferred to Brassica napus by introgressions originating from $B$. juncea or B. nigra B genome. Phytopathology 89:1200-1213.

Introgressions into Brassica napus from the B genome, either the $B$. nigra chromosome B4 or the B. juncea fragment carrying the Jlm 1 gene, have given rise to the $B$. napus-B. nigra addition line (LA4+) and the $B$. napus- $B$. juncea recombinant line (MXS), respectively. The resistance of these two lines to Leptosphaeria maculans is characterized by a hypersensitive reaction (HR) on both the cotyledons and leaves, while the col-

phasis on cytological events underlying the HR and on host defense reactions. Features of host cell changes including condensation and lobing of nuclei, fragmentation of chromatin, disruption of the nuclear membranes, and plasma membrane withdrawal were reminiscent of HR cell death in MXS and LA4+ plants. Restriction of pathogen growth to the infection areas in LA4+ was correlated to reinforcement of cell wall barriers, including wall apposition, papillae, and vessel plugging. In MXS, the lower expression of resistance was associated with a delay in plant responses. These results indicate that mechanisms underlying the HR in the B. napus recombinant and addition lines are differently controlled according to the introgressed genes.
\end{abstract} lar displays a high degree of resistance. Responses induced in cotyledons of the two lines by L. maculans inoculation were investigated with em-

Blackleg, caused by Leptosphaeria maculans (Desmaz.) Ces. \& De Not. (anamorph Phoma lingam (Tode:Fr.) Desmaz.), is one of the most threatening diseases of Brassica, including oilseed rape (B. napus L. var. oleifera; AACC, $2 \mathrm{n}=38$ ). After invading the leaf mesophyll in susceptible plants, the fungus reaches the vascular bundle and colonizes the plant via petioles and stems (16). This intercellular systemic phase of growth is biotrophic and symptomless. It is followed by invasion of cortical cells in the basal part of the stem and subsequent development of collar necrosis. This necrotrophic phase results in the formation of stem canker, leading to lodging, which is the most damaging manifestation in the field. Because control of the disease by cultural and chemical practices is currently inadequate, the use of resistant cultivars has become the most promising strategy for sustainable management of blackleg.

Two types of resistance in B. napus have been identified. The first type, which occurs at the seedling stage, is thought to be mono- or oligogenic $(2,24,27)$, whereas the second type is partial and polygenic $(13,26)$ and only expressed at the collar level, though cotyledons and leaves remain susceptible. Because the resistance to $L$. maculans expressed by most commercial cultivars of B. napus does not prevent significant crop losses, an increase in resistance has become a major challenge in oilseed rape breeding programs.

Brassica species containing the $\mathrm{B}$ genome, such as $B$. juncea (L.) Czern. (AABB, $2 \mathrm{n}=36)$ and B. nigra (L.) W. Koch $(\mathrm{BB}, 2 \mathrm{n}=$ 16 ), generally exhibit a hypersensitive response (HR) to L. maculans at the cotyledon stage. This resistance is thought to be monoor oligogenic $(19,20,27,33)$. Recently, introgression of either the $B$. nigra chromosome $\mathrm{B} 4$ or the $B$. juncea Jlm1 gene into B. napus has given rise to a $B$. napus- $B$. nigra addition line (LA4+; AACC +

Corresponding author: H. Brun; E-mail address: brun@rennes.inra.fr

Publication no. P-1999-1018-01R

(C) 1999 The American Phytopathological Society
Additional keywords: HR-type symptoms, resistance gene. chromosome $\mathrm{B} 4,2 \mathrm{n}=38+1)$ and a $B$. napus-B. juncea recombinant line (MXS; AACC, $2 \mathrm{n}=38$ ), respectively $(8,9)$. Resistance in the MXS and LA4+ lines, efficient under artificial and field conditions, is characterized by a HR on cotyledons and leaves and by a high degree of resistance at the collar level $(8,9)$. Recent genetic investigations demonstrated that the genes borne by each introgression had two different locations on the B genome; three markers, tightly linked to the Jlml gene from $B$. juncea, were located on the chromosome B8 from B. nigra cv. Junius, but not on the chromosome B4 (8).

Biochemical analyses revealed that the HR of B. juncea to $L$. maculans correlated with the production of the phytoalexin brassilexin, which accumulated in $B$. juncea earlier and more intensely than in B. napus following an abiotic elicitation (32). In the B. napus$B$. juncea interspecific progenies, phytoalexin accumulation was less intense than in B. juncea, but greater than in B. napus cultivars susceptible to $L$. maculans (31). Resistance in the $B$. juncea cotyledons was correlated with the restriction of hyphal growth, production of callose, and accumulation of a brownish material in the mesophyll cells (7).

In spite of major advances in our understanding of the events involved in the resistance of B. juncea to L. maculans, the mechanisms governed by resistance genes from the B genome and expressed in B. napus, B. juncea, and B. nigra are still controversial. In that context, further investigation into the resistance mechanisms to $L$. maculans conferred in B. napus by introgressed genetic material is essential to characterize and compare the responses induced in the B. napus AACC genome by the Jlml gene and the chromosome B4. In the current histological and cytological study, we investigated the infection process of an A-group L. maculans isolate, avirulent on $B$. juncea cv. Picra and MXS and LA4+ lines and virulent on B. napus cvs. Darmor and Samouraï, with particular emphasis on the ultrastructure of tissues undergoing HR and host defense reactions. In the MXS and LA4+ lines, evidence 
is provided that shows that the HR phenotype is associated with cell death features, restriction of pathogen growth, and elaboration of various host responses.

\section{MATERIALS AND METHODS}

Plant material. Two oilseed rape lines resistant to $L$. maculans were previously obtained through interspecific crosses between $B$. napus and either $B$. juncea or B. nigra cultivars. The first was the $B$. napus- $B$. juncea recombinant line MXS (B. napus cv. Samouraï carrying one resistance gene [Jlml] from $B$. juncea) (8). The second was the B. napus-B. nigra addition line LA4+ (B. napus cv. Darmor carrying the chromosome B4 from B. nigra cv. Junius, responsible for resistance at the cotyledon stage) (9). Both the MXS and LA4+ lines are winter-type brassicas.

The winter-type B. napus cvs. Samouraï and Darmor (from INRA-SERASEM, La Chapelle d'Armentieres, France) (susceptible at the cotyledon stage), the resistant spring-type $B$. juncea cv. Picra, and the MXS and LA4+ lines were used in this study. Because cotyledons of the resistant spring-type $B$. nigra cv. Junius exhibited yellowing and chlorosis in our experimental conditions, cytological investigations were not carried out with this cultivar.

Seeds from each cultivar were sown in a sterilized soil mixture (sand/loam/compost, 1:1:1) in $7 \times 7 \times 8$-cm plastic pots and grown, under a 12 -h photoperiod, in a growth cabinet at $15^{\circ} \mathrm{C}$. Before inoculation of the plants, leaves were removed as they developed in order to prevent early senescence of cotyledons. Preliminary tests showed that cotyledon reaction was not modified by leaf removal (H. Brun, unpublished data).

Fungal culture. The single-ascospore isolate A290 of L. maculans, obtained from oilseed rape stem residues, was assigned to the A group (highly aggressive) by isozyme banding pattern and pigment production (36) and belonged to pathogenicity group 4 (PG4) (H. Brun, unpublished data) according to virulence tests on the three differential cvs. Westar, Glacier, and Quinta (24). Pycnidiospore suspensions were produced as described by Somda et al. (36) and adjusted to a final concentration of $10^{7}$ pycnidiospores per $\mathrm{ml}$.

Inoculation test. Cotyledons of 20 plants per genotype were inoculated 10 days after sowing. Immediately before inoculation, a small puncture was made in the middle of each cotyledon lobe (four inoculation sites per plant) with a thin sterile needle. Preliminary tests showed that wounding was necessary to ensure homogeneous infection and to generate consistent results (S. Roussel, unpublished data). A 10- $\mu$ l droplet of the pycnidiospore suspension was deposited on each wound using an Eppendorf repeater pipette. Inoculated plants were then incubated in darkness for $24 \mathrm{~h}$ at $20^{\circ} \mathrm{C}$ and $100 \%$ relative humidity. Ten untreated plants and 10 wounded plants with a drop of sterile water deposited in place of inoculum were used as controls in each experiment. Compatible interactions included the B. napus cv. Samouraï-PG4 and B. napus cv. DarmorPG4 interactions, and incompatible interactions included the $B$. juncea cv. Picra-PG4, MXS-PG4, and LA4+-PG4 interactions.

Evaluation of disease severity. Cotyledon reactions were classified according to lesion size 12 days after inoculation (d.a.i.), using the 0 (no visible symptoms) to 9 (collapse of tissue) rating scale of Williams and Delwiche (39). Plants in classes 1 to 5 were considered resistant to L. maculans, and plants in classes 6 to 9 , susceptible. A disease index was calculated as DI $=\Sigma\left(N_{i} \times i\right) / N_{t}$, in which $N_{i}$ represents the number of inoculation sites with disease score $i(i=0$ to 9 ) and $N_{t}$ represents the total number of inoculation sites.

Electron microscopy. Fragments $(3 \times 2 \mathrm{~mm})$ centered on the wounds were excised from untreated, water-control, and inoculated cotyledons $1,2,3,5,8$, and 12 d.a.i. For each genotype and observation date, eight inoculated sites from different plants together with four fragments from each of the two controls were examined under a light microscope. Electron microscopy observations were made on three inoculated sites, two water-infiltrated sites, and two untreated sites per genotype and per observation date.
To facilitate observations, three zones were defined around the infection site in the mesophyll: zone A, two cellular layers adjacent to the wounding zone; zone B, three cellular layers adjacent to zone $\mathrm{A}$; and zone $\mathrm{C}$, three cellular layers adjacent to zone $\mathrm{B}$.

For histochemistry and immunocytochemistry, cotyledon fragments were fixed for $2 \mathrm{~h}$ in $1 \%$ (vol/vol) glutaraldehyde (Sigma Chemical Co., St. Louis) and 4\% (vol/vol) paraformaldehyde (Sigma Chemical Co.) buffered with $0.1 \mathrm{M}$ sodium cacodylate (Sigma Chemical Co.), pH 7.2. Samples were rinsed in the same buffer, dehydrated in a graded series of ethanol, and embedded in LR White resin (London Resin Co., TAAB, Reading, England).

For conventional electron microscopy and cytochemistry, samples were fixed for $2 \mathrm{~h}$ in $4 \%$ ( $\mathrm{vol} / \mathrm{vol}$ ) glutaraldehyde buffered with $0.1 \mathrm{M}$ sodium cacodylate, $\mathrm{pH} 7.2$, postfixed for $1 \mathrm{~h}$ in $1 \%$ (vol/vol) osmium tetroxide (Sigma Chemical Co.) $\left(\mathrm{OsO}_{4}\right)$ in water, dehydrated in ethanol, and embedded in Epon 812 resin (TAAB, Reading, England).

Ultrathin sections ( 80 to $90 \mathrm{~nm}$ ) were stained with uranyl acetate (Sigma Chemical Co.), followed by lead citrate (E. Merck AG, Damstadt, Germany), before being examined under a JEOL 100EX transmission electron microscope (JEOL, Ltd., London) operating at $80 \mathrm{kV}$.

Histochemistry. Semithin sections (1 to $2 \mu \mathrm{m}$ ) of fragments embedded in LR White resin were stained with $1 \%$ toluidine blue (Sigma Chemical Co.) in borax (Sigma Chemical Co.), pH 8.9, and observed under the Diaplan light microscope (Leitz, Lyon, France). A pink staining indicated the presence of pectic-like components. The percentage of xylem vessels occluded by pectic compounds was based upon the ratio between the number of occluded vessels and the number of observed vessels on a section. The number of observed vessels on a section was estimated to be 20 . One section per block was observed, and four blocks were examined. Hyphae were also monitored in zones $\mathrm{A}, \mathrm{B}$, and $\mathrm{C}$ on each section.

Autofluorescence of phenolics was investigated on semithin sections embedded in LR White resin examined by epifluorescence microscopy using both a UV filter set (365-nm excitation and 400-nm barrier filter) and a blue filter set (420-nm excitation and 515- to 560 -nm barrier filter) to detect the presence of phenolic compounds.

Cytochemistry. Cytolocalization of $\beta$-1-4-glucans was performed using a purified $\beta$-1-4-exoglucanase complexed to colloidal gold at $\mathrm{pH} 9.0$ in $0.1 \mathrm{M}$ phosphate-buffered saline (PBS) polyethylene glycol (PEG) (0.01 M) (4). Sections were incubated for $30 \mathrm{~min}$ at $37^{\circ} \mathrm{C}$ on a drop of the gold probe (dilution $1 / 4, \mathrm{pH} 6.5$ ) before rinsing with PBS, washing in distilled water, and staining. Specificity of the labeling was assessed by incubating sections with the goldcomplex protein previously saturated with an excess of $\beta-1-4$-glucans from barley.

Immunocytochemistry. Polyclonal antibodies raised against $\beta$ 1-3-glucans (Cambridge Research Biochemicals, Cardiff, United Kingdom) were used to immunolocalize callose. Sections from cotyledons were incubated for $30 \mathrm{~min}$ at $37^{\circ} \mathrm{C}$ on a drop of primary antibodies (in 1/500 $0.1 \mathrm{M}$ PBS [pH 7.2], $0.5 \%$ bovine serum albumin, and $0.05 \%$ Tween) and rinsed with PBS before being incubated on gold-labeled goat anti-rabbit antibodies (1/20) (GAR-15; BioCell Research Laboratories, Cardiff, United Kingdom).

The monoclonal antibody JIM 5, raised against epitopes of unesterified pectin, was used to detect galacturonic acid-containing molecules. Immunogold localization of pectin was performed as described by Knox et al. (21). Sections were incubated on a drop of the primary antibody for $2 \mathrm{~h}$ at $37^{\circ} \mathrm{C}$ and then on a drop of a gold-labeled goat anti-rat antibodies (GAT 15) for $30 \mathrm{~min}$ at $37^{\circ} \mathrm{C}$.

Specificity of labeling was assessed through the following control experiments performed on sections from untreated and infected cotyledons: (i) incubation with the antiserum previously adsorbed with the antigen, laminarin, and galacturonic acids, respectively; (ii) incubation with preimmune rabbit or rat serum instead of the primary antiserum; and (iii) omission of the primary antibody incubation step. 


\section{RESULTS}

Symptoms. By 12 d.a.i., cotyledon lesions reached 5 to $9 \mathrm{~mm}$ in diameter in the compatible interactions B. napus cv. SamouraïPG4 and B. napus cv. Darmor-PG4, with an average disease index of $7.9 \pm 1.2$ and $6.4 \pm 1.9$, respectively. In the incompatible interaction $B$. juncea cv. Picra-PG4, the diameter of HR-induced lesions never exceeded $3 \mathrm{~mm}$, with an average disease index of $1.9 \pm 0.8$ at 12 d.a.i. In the incompatible interactions, B. napus- $B$. juncea MXS-PG4 and B. napus-B. nigra LA4+-PG4, the lesions reached 1 to $5 \mathrm{~mm}$ in diameter, with a disease index of $3.8 \pm 1.2$ and $2.6 \pm$ 0.9 , respectively, at 12 d.a.i. Due to variability in the diameter of lesions, microscopic investigations on the MXS and LA4+ lines were carried out on the plants that appeared to be the most resistant to L. maculans (plants exhibiting small brown necrotic symptoms). No visible symptoms were observed in plants treated with water.

Colonization of cotyledon tissues by $L$. maculans. Light microscopy revealed that, in all genotypes, hyphae were localized in intercellular areas of the mesophyll. In the lesions of the susceptible cv. Samouraï, hyphae were detected as soon as 3 d.a.i. in zones A and $\mathrm{B}$ and 5 d.a.i. in zone $\mathrm{C}$. The intensity of colonization increased between 8 and 12 d.a.i., with hyphae multiplying abundantly in the three zones (Table 1). In the susceptible B. napus cv. Darmor, hyphae were detected 5 d.a.i. in the three zones. The intensity of colonization increased progressively up to 12 d.a.i. in the three zones (Table 1). Damaged hyphae with degraded or empty cells were never observed in either genotype at that time.

In the lesions of the resistant $B$. juncea $\mathrm{cv}$. Picra, hyphae appeared only at 5 d.a.i. (Table 1). The few hyphae were consistently seen in zones $\mathrm{A}$ and $\mathrm{B}$ and seldom seen in zone $\mathrm{C}$, except after 8 d.a.i. An average of $30 \%$ of the fungal cells showed an altered cytoplasm, including vacuolation of the cytoplasm and disorganization of organelles, at 5 d.a.i. (data not shown).
Within the lesions of the MXS line, hyphae were detected 3 d.a.i. and colonized the three zones at 5 d.a.i. The level of colonization was similar to that observed at up to 8 d.a.i. in the susceptible cv. Samouraï, but was lower than that observed in the susceptible cv. Samouraï at 12 d.a.i. (Table 1). Within the lesions of the LA4+ line, hyphae were not detected before 12 d.a.i. (Table 1). At that time, the level of colonization in the three zones was very low. Hyphae showing signs of damage were seen in both lines.

Obstruction of xylem vessels. In the compatible interaction $B$. napus cv. Samouraï-PG4, a material that stained pink with toluidine blue accumulated in the lumen of $8 \%$ of the xylem vessels at 5 d.a.i. This percentage increased to $97 \%$ by 12 d.a.i. (Table 2). In the compatible interaction B. napus cv. Darmor-PG4, $56 \%$ of the vessels were obstructed at 8 d.a.i., increasing to $87 \%$ by 12 d.a.i. In the incompatible interaction $B$. juncea cv. Picra-PG4, $49 \%$ of the vessels were occluded at 5 d.a.i. and $98 \%$, at 12 d.a.i. (Table 2).

In the incompatible interaction MXS-PG4, no vessels were seen occluded at 5 d.a.i., but 75 and $91 \%$ contained an occluding material by 8 and 12 d.a.i., respectively. In the incompatible interaction LA4+-PG4, 57 and 97\% of the vessels showed a pink material at 8 and 12 d.a.i., respectively (Table 2). In the controls, no material was seen in the vessels.

Autofluorescence. Except for lignin fluorescence in secondary vessel cell walls, no autofluorescence was observed on sections from any of the genotypes when infected with L. maculans.

Ultrastructural changes of host cells in the compatible interaction. Infection of cotyledons from the susceptible cv. Samourai was accompanied by severe alterations of middle lamellae (Fig. 1A, arrows). Swelling of primary cell walls and lysis were noticed in areas adjacent to the pathogen. Eight days after inoculation, the cytoplasm of infected tissues was disorganized, including retraction of the plasmalemma from the cell wall. Wall appositions (deposition of wall material along the cell wall in the paramural area, with

TABLE 1. Intensity of cotyledon colonization by the Leptosphaeria maculans pathogenicity group 4 isolate in Brassica genotypes

\begin{tabular}{|c|c|c|c|c|c|c|c|c|c|c|c|c|}
\hline \multirow[b]{3}{*}{ Plant genotype (L. maculans-genotype interaction) } & \multicolumn{12}{|c|}{ Time (days) after inoculation } \\
\hline & \multicolumn{3}{|c|}{3} & \multicolumn{3}{|c|}{5} & \multicolumn{3}{|c|}{8} & \multicolumn{3}{|c|}{12} \\
\hline & $\mathrm{A}^{\mathrm{x}}$ & $\mathrm{B}$ & $\mathrm{C}$ & A & $\mathrm{B}$ & $\mathrm{C}$ & A & $\mathrm{B}$ & $\mathrm{C}$ & A & $\mathrm{B}$ & $\mathrm{C}$ \\
\hline B. napus cv. Samouraï (compatible) & $3 \pm 0.7^{y}$ & $1 \pm 0.2$ & $\ldots{ }^{\mathrm{z}}$ & $3 \pm 0.9$ & $1 \pm 0.8$ & $2 \pm 1$ & $4 \pm 1.9$ & $4 \pm 2.1$ & $2 \pm 1.4$ & $29 \pm 3$ & $34 \pm 2.8$ & $31 \pm 2.4$ \\
\hline B. napus cv. Darmor (compatible) & $\ldots$ & $\ldots$ & $\ldots$ & $2 \pm 0.6$ & $1 \pm 0.9$ & $1 \pm 1.2$ & $11 \pm 3$ & $6 \pm 1.6$ & $2 \pm 1.4$ & $27 \pm 2.2$ & $22 \pm 1.8$ & $21 \pm 1.8$ \\
\hline B. juncea cv. Picra (incompatible) & $\ldots$ & $\ldots$ & $\ldots$ & 1 & $1 \pm 0.6$ & $\ldots$ & $2 \pm 0.4$ & $1 \pm 0.3$ & $1 \pm 0.5$ & $3 \pm 0.5$ & $1 \pm 0.6$ & $2 \pm 0.2$ \\
\hline B. napus-B. juncea recombinant MXS line (incompatible) & $2 \pm 0.4$ & $1 \pm 0.2$ & $\ldots$ & $4 \pm 0.8$ & 1 & $1 \pm 0.1$ & $5 \pm 1.1$ & $3 \pm 1.6$ & 1 & $16 \pm 2.1$ & $12 \pm 2.3$ & $11 \pm 2$ \\
\hline B. napus-B. nigra addition LA4+ line (incompatible) & $\ldots$ & $\ldots$ & $\ldots$ & $\ldots$ & $\ldots$ & $\ldots$ & $\ldots$ & $\ldots$ & $\ldots$ & $3 \pm 1.1$ & $2 \pm 1.3$ & $1 \pm 1.5$ \\
\hline
\end{tabular}

x Zones are defined from the wounding zone: A, two cellular layers adjacent to the wounding zone; $\mathrm{B}$, three cellular layers adjacent to zone A; and C, three cellular layers adjacent to zone B.

${ }^{y}$ The intensity of mycelial colonization of host tissues was evaluated as follows. Hyphae were counted in zones A, B, and C. Two sections per sample were observed and two samples per plant were examined. Five plants were observed. Each value represents the mean of 20 measurements \pm standard deviation. z $\ldots=$ Absence of mycelium.

TABLE 2. Intensity of staining with toluidine blue of vessel-accumulated material and percentage of occluded vessels in cotyledons of three Brassica genotypes following Leptosphaeria maculans inoculation

\begin{tabular}{|c|c|c|c|c|c|}
\hline \multirow[b]{2}{*}{ Plant genotype (L. maculans-genotype interaction) } & & \multicolumn{4}{|c|}{ Time (days) after inoculation } \\
\hline & & 3 & 5 & 8 & 12 \\
\hline \multirow[t]{2}{*}{ B. napus cv. Samouraï (compatible) } & $\mathrm{i}^{\mathrm{x}}$ & $-\mathrm{y}$ & $+\left(8 \pm 0.9^{z}\right)$ & $++(77 \pm 5.2)$ & $+++(97 \pm 6.3)$ \\
\hline & $c^{x}$ & - & - & - & - \\
\hline \multirow[t]{2}{*}{ B. napus cv. Darmor (compatible) } & $\mathrm{i}$ & - & - & $++(56 \pm 3.5)$ & $+++(87 \pm 9)$ \\
\hline & $\mathrm{c}$ & - & - & - & - \\
\hline \multirow[t]{2}{*}{ B. juncea cv. Picra (incompatible) } & $\mathrm{i}$ & - & $+(49 \pm 0.8)$ & $++(81 \pm 5.1)$ & $+++(98 \pm 5.6)$ \\
\hline & $\mathrm{c}$ & - & - & - & - \\
\hline \multirow[t]{2}{*}{ B. napus-B. juncea recombinant MXS line (incompatible) } & $\mathrm{i}$ & - & - & $++(75 \pm 5.9)$ & $+++(91 \pm 6)$ \\
\hline & $\mathrm{c}$ & - & - & - & - \\
\hline \multirow[t]{2}{*}{ B. napus-B. nigra addition LA4+ line (incompatible) } & $\mathrm{i}$ & - & - & $++(57 \pm 6.2)$ & $+++(97 \pm 5.8)$ \\
\hline & $\mathrm{c}$ & - & - & - & - \\
\hline
\end{tabular}

$\mathrm{x} \mathrm{i}=$ Inoculated cotyledons; and $\mathrm{c}=$ controls (water-treated or nontreated cotyledons).

y Intensity of staining: -, none; +, weak; ++, medium; and +++, intense.

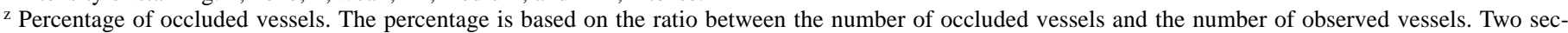
tions per block and two blocks per plant were observed. Four plants were examined. Each value is presented \pm standard deviation. 
no particular location) and papillae (localized deposition of wall material in the paramural area, close to the pathogen) were often seen in the vicinity of hyphae and were always located in zone B (Table 3). The occluding material accumulating in xylem vessels displayed a fibrillar structure (Fig. 1B). In L. maculans-inoculated cotyledons of the susceptible cv. Darmor, the pattern of fungal infection and host modifications was similar to that described in the susceptible cv. Samouraï. Wall appositions were detected 5 d.a.i. in zones A and B (Table 3). The only visible papillae (Fig. 1C) were detected 5 d.a.i. in zone A. In the cv. Darmor, wall appositions and papillae were observed, but with a lower intensity than in the cv. Samouraï.

Ultrastructural changes of host cells in the incompatible interaction. In the resistant cv. Picra, no apparent cell wall degra-
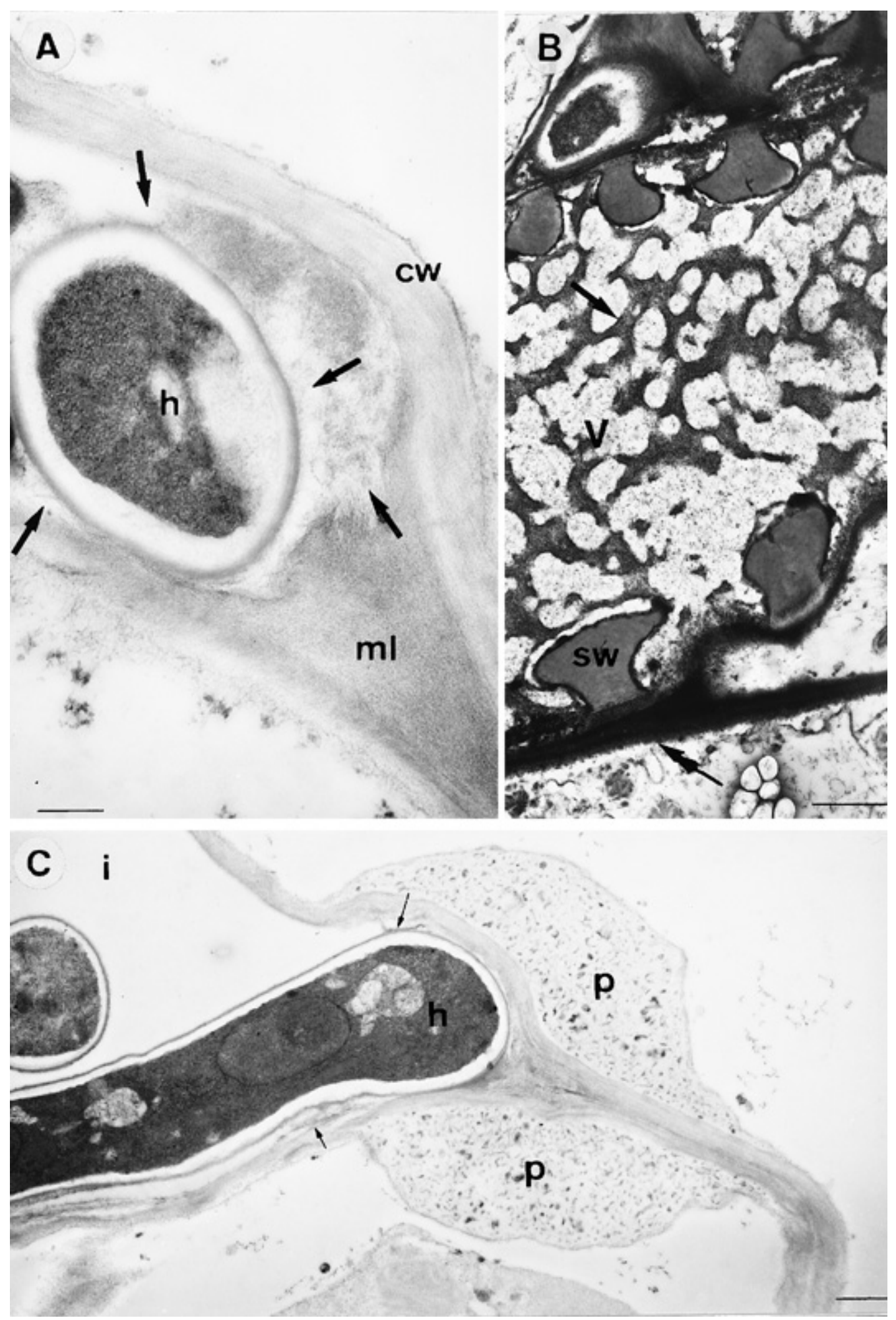

Fig. 1. Transmission electron micrographs of transverse sections of Leptosphaeria maculans-inoculated cotyledons of the susceptible Brassica napus cvs. Samourai and Darmor. Glutaraldehyde and osmium tetroxide fixation 12 days after inoculation. A, Degradation of middle lamella (ml; arrows) is seen close to the fungal hypha (h) in the cv. Samouraï. Bar $=0.3 \mu \mathrm{m}$. B, The lumen of a xylem vessel (V) is occluded by a fibrillar material (arrow) that is closely associated with the secondary cell wall (sw). The middle lamella is highly electron dense (double arrow). Bar $=0.1 \mu \mathrm{m}$. C, Two papillae (p) are localized in the periplasmic areas of cells adjacent to the intercellular hypha $(\mathrm{h})$ in $\mathrm{cv}$. Darmor. The middle lamella and the cell wall (cw) show degradation patterns (arrows). $\mathrm{i}=\mathrm{Intercellular}$ space. $\mathrm{Bar}=0.8 \mu \mathrm{m}$. 
dation was observed. Wall appositions were observed by 3 d.a.i. and were usually found in zones $\mathrm{A}$ and $\mathrm{B}$, but not in zone C, except by 12 d.a.i. (Table 3), when they showed a fibrillar-like organization with electron-dense bodies (Fig. 2A, arrows). Papillae were detected earlier in cv. Picra (5 d.a.i.) than in cotyledons of the susceptible cv. Samouraï ( 8 d.a.i.) The material that accumulated in the lumen of vessels also showed a fibrillar organization (Fig. 2B). The main changes detected in the host cells were characterized by a spatial reorganization of the tonoplast invaginated into the cytoplasm (Fig. $2 \mathrm{C})$ by 3 to 8 d.a.i. in the three zones. In addition, enhanced vacuolation (Fig. 2D), localization of mitochondria close to the plasma membrane, fragmentation of the chromatin (Fig. 3A), and presence of highly lobed nuclei were striking features observed in the three zones of plants exhibiting HR.

In the resistant recombinant MXS line, no apparent cell wall degradation was observed. Wall appositions and papillae were similar to those observed in the cvs. Samouraï and Picra. Wall appositions were observed by 3 d.a.i. in zone A and by 12 d.a.i. in zone C (Table 3). Papillae were seen by 8 d.a.i. and extended to the three zones by 12 d.a.i. The vessel-accumulating material was similar in structure and electron density to that observed in the resistant $\mathrm{cv}$. Picra and susceptible cv. Samouraï. Invagination of the tonoplast into the cytoplasm, similar to that observed in the resistant cv. Picra, was seen by 3 d.a.i. Vacuolation, localization of mitochondria close to the plasma membrane, and lobed nuclei with fragmented chromatin were also typical features observed in the cytoplasm of parenchyma cells by 3 d.a.i.

In the resistant addition LA4+ line, no apparent cell wall degradation was observed. Wall appositions were found in zone A by 5 d.a.i. and in zone B by 12 d.a.i. No papillae were detected (Table 3). Invagination of the tonoplast, vacuolation, fragmentation of chromatin, and highly lobed nuclei (Fig. 3B) were also observed in this line at 3 d.a.i. The material that accumulated in the lumen of vessels was similar to that described above.

Wall appositions, formation of papillae, and occlusion of vessels by a fibrillar material were observed in the LA4+ line at the same location and with a similar intensity as in cv. Darmor, but at a lower intensity than in the MXS line.

Our observations in mesophyll and vascular parenchyma cells were reproducible from one sample to another for the cvs. Picra and Samouraï and the MXS line. In such cultivars, the magnitude of the host reactions was high. By contrast, a great variability between samples with respect to wall appositions, papillae, and vessels obstruction was observed in both the cv. Darmor and LA4+ line.

Compared with the untreated cotyledons, wall appositions were the only ultrastructural features found in sections from water-control cotyledons. They were observed in all genotypes by 3 days after wounding. As they appeared only in the zone A, the closest zone to the wound, they may likely result from wounding during inoculation. Nuclei did not display any morphological changes (Fig. 4A).

Cytochemical localization of $\beta$-1,4-glucans. In the susceptible cv. Samouraï, the interface between hyphae and mesophyll cells was characterized by a marked modification of the primary cell wall (Fig. 5A), with areas showing a weaker labeling with the exoglucanase-gold complex (Fig. 5A, arrows) as compared with unmodified wall portions. In the susceptible cv. Darmor, labeling was associated with detached fragments of the cell walls (Fig. 5B), but labeling was absent over wall appositions and papillae (data not shown).

In contrast, cell wall modifications were not observed in the resistant cv. Picra and the MXS and LA4+ lines (Fig. 5C). Wall appositions (Fig. 6A) were slightly labeled by the exoglucanase probe in cvs. Samouraï and Picra and the MXS and LA4+ lines. Labeling of papillae was positive in the cv. Samouraï (data not shown). Gold particles were also seen over compounds occluding vessels in the resistant cv. Picra (Fig. 6B), but not in the other genotypes (Fig 6C). In the controls, labeling over the cell walls was regularly distributed (Fig. 4B).

Immunocytochemical localization of $\beta$-1-3-glucans. Labeling of papillae occurred in the cvs. Samouraï, Picra, and Darmor (Fig. 7A) and the MXS line (Fig. 7B). Gold particles were distributed over wall appositions in cvs. Picra and Darmor and the MXS line (Fig. 7C), but not in cv. Samouraï or the LA4+ line. No labeling of the fibrillar material accumulating in vessels was observed; in contrast, the fungal cell wall showed uneven distribution of gold particles. Incubation of sections of control plants with the anti- $\beta$ 1-3-glucans polyclonal antibody did not reveal any significant labeling.

Immunocytochemical localization of pectin. In the $\mathrm{cv}$. Samouraï, incubation of sections with the JIM 5 anti-pectin mono-

TABLE 3. Ultrastructural changes of host cells in Leptosphaeria maculans-inoculated or control cotyledons of Brassica genotypes

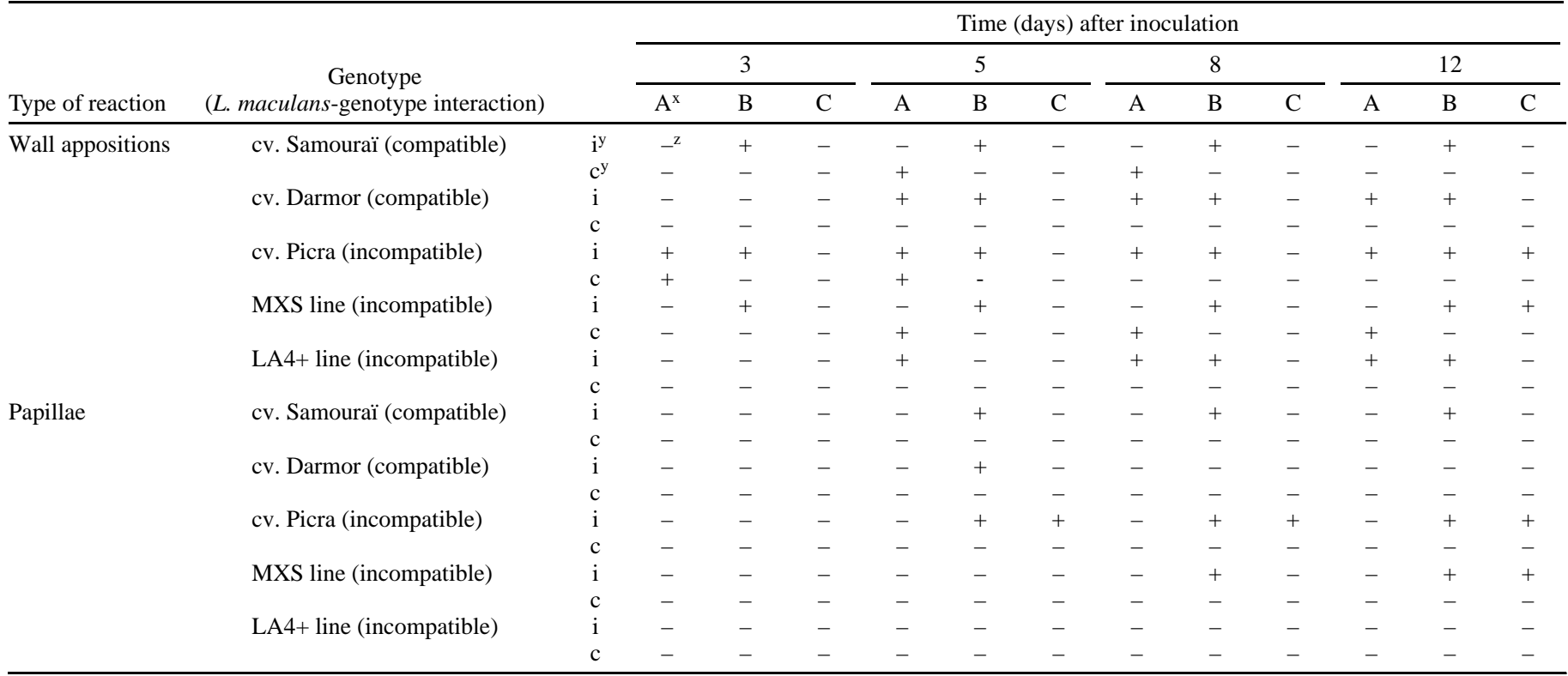

${ }^{\mathrm{x}}$ Zones are defined from the wounding zone: A, two cellular layers adjacent to the wounding zone; $\mathrm{B}$, three cellular layers adjacent to zone A; and C, three cellular layers adjacent to zone B.

y $\mathrm{i}=$ Inoculated cotyledons; and $\mathrm{c}=$ water-control cotyledons.

${ }^{\mathrm{z}}$ Rating scale: - , reaction absent; and + , reaction present. 

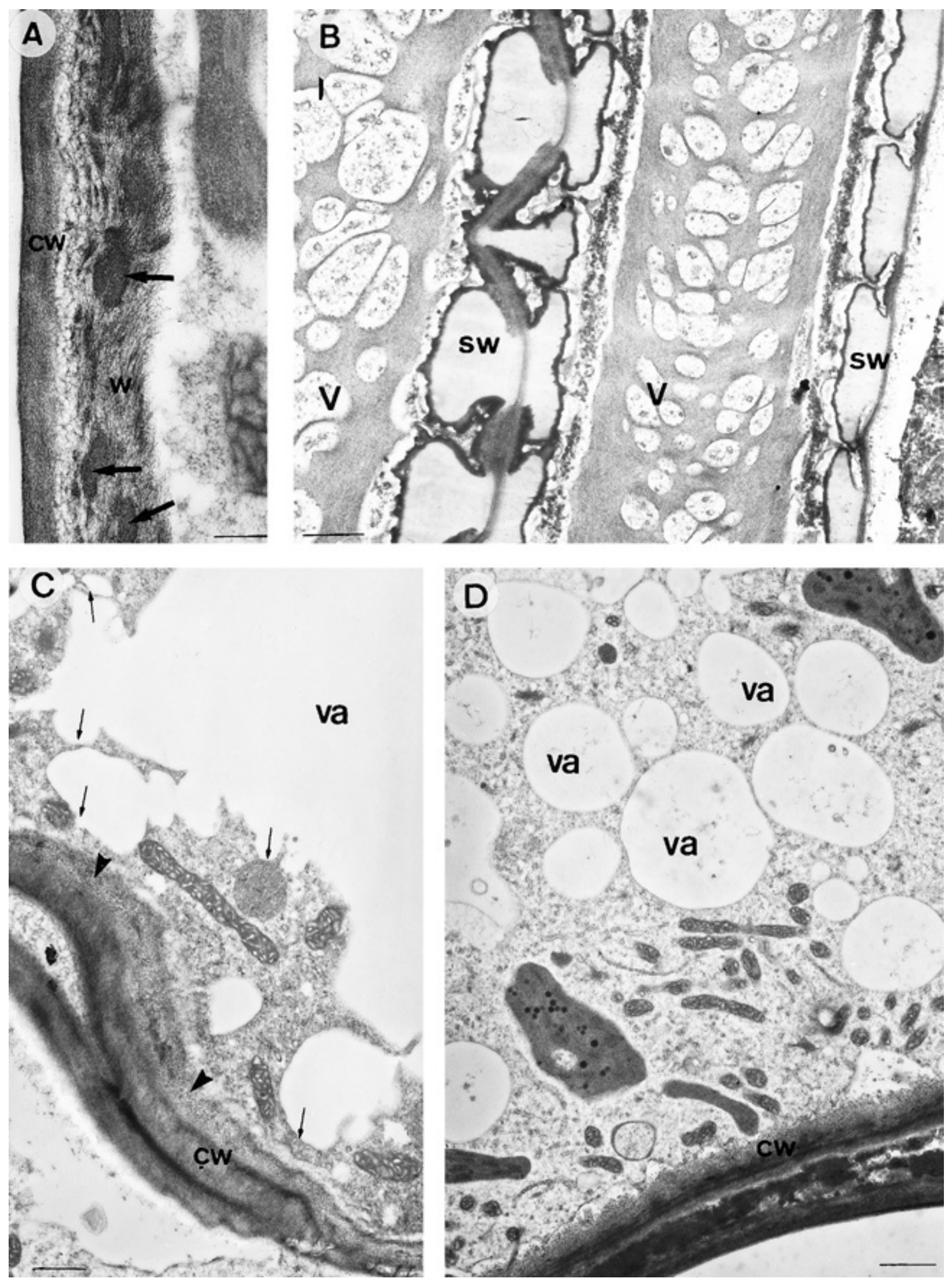

Fig. 2. Transmission electron micrographs of transverse sections of Leptosphaeria maculans-inoculated cotyledons of the resistant Brassica juncea cv. Picra. Glutaraldehyde and osmium tetroxide fixation 12 days after inoculation. A, Electron-dense bodies (arrows) are included in the fibrillar material of a wall apposition $(\mathrm{w})$ in the paramural area of a parenchyma cell. Bar $=0.3 \mu \mathrm{m}$. B, The material that accumulates in the xylem vessels $(\mathrm{V})$ displays a fibrillar texture. sw $=$ Secondary cell wall. Bar $=1.2 \mu \mathrm{m}$. C, The tonoplast shows invaginations (arrows) from the vacuole (va) into the cytoplasm of a parenchyma cell. A fibrillar wall apposition (arrowheads) is seen close to the cell wall (cw). Bar $=0.5 \mu \mathrm{m}$. D, The marked vacuolation (va) in the cytoplasm of this parenchyma cell is associated with localization of numerous mitochondria close to the plasmalemma. $\mathrm{cw}=$ Cell wall. $\mathrm{Bar}=1.2 \mu \mathrm{m}$. 
clonal antibody resulted in a general labeling of primary cell walls and middle lamellae of infected cells (Fig. 8A). Altered areas of middle lamellae were associated with an uneven labeling (Fig. 8A). Papillae were labeled in the cv. Samouraï, but not in the cvs. Picra and Darmor and the MXS and LA4+ lines. Wall appositions were labeled in cvs. Samouraï and Picra (Fig. 8B), but not in cv. Darmor or the MXS and LA4+ lines. In all genotypes, the material that occluded vessels was evenly but slightly labeled (Fig. 8C and D). In control plants, gold particles were distributed regularly over middle lamellae (Fig. 4C).

\section{DISCUSSION}

The current microscopic study investigated plant cytological responses induced by resistance genes to L. maculans of the B ge- nome expressed in B. napus. We demonstrated that restriction of pathogen growth and expression of host defense reactions in the $B$. napus- $B$. juncea recombinant line (MXS) are different from those observed in the B. napus-B. nigra addition line (LA4+).

This analysis clearly emphasizes variations in location and timing of the cytological responses in both the compatible and incompatible interactions, including the infected introgressed B. napus lines. In the susceptible cvs. Samouraï and Darmor, the strong and extended fungal colonization of cotyledon tissues was associated with an important cell wall + degradation pattern. Cytochemical evidence for pectin and cellulose alteration close to L. maculans suggests the production of fungal hydrolases such as polygalacturonases and cellulases, the activity of which could be responsible for degradation of middle lamellae and cell walls $(1,11,17)$. The local weakening or loosening of the host cell walls likely facili-
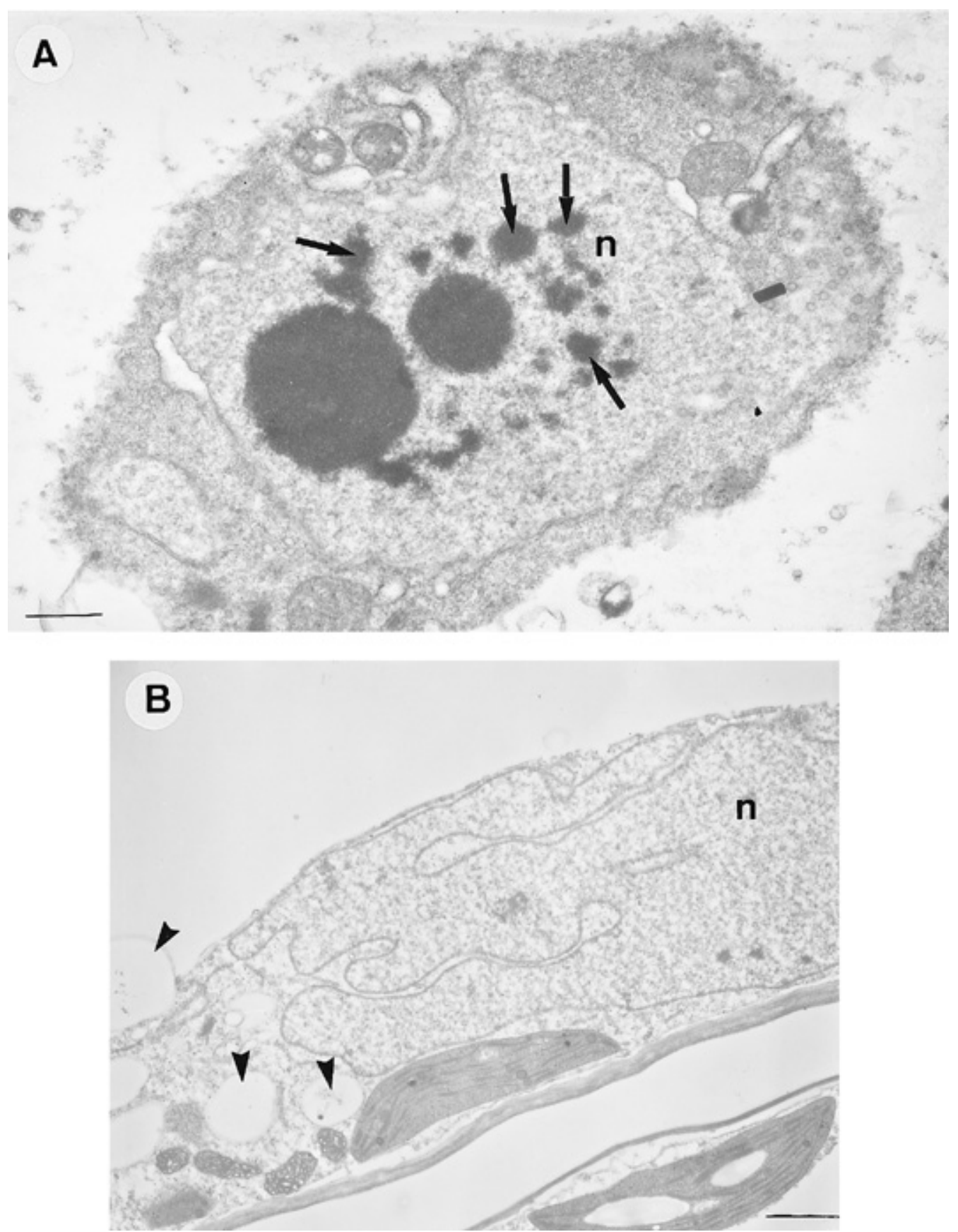

Fig. 3. Transmission electron micrographs of transverse sections of Leptosphaeria maculans-inoculated cotyledons. Glutaraldehyde and osmium tetroxide fixation 8 days after inoculation. A, In the resistant Brassica juncea cv. Picra, chromatin in the nucleus (n) of a parenchyma vascular cell shows a highly fragmented pattern (arrows). Bar $=0.6 \mu \mathrm{m}$. B, In the resistant B. nigra-B. napus addition line (LA4+), the highly lobed nucleus (n) of a parenchyma cell is associated with vacuolation (arrowheads) of the cytoplasm. Bar $=1.2 \mu \mathrm{m}$. 
tated fungal ingress inside leaf tissues. By contrast, during the incompatible interactions $B$. juncea cv. Picra- $L$. maculans, MXSL. maculans, and LA4+-L. maculans, the low rate of host invasion by the pathogen was associated with an apparent integrity of the host cell walls that did not display any striking modification of labeling. This suggests that inhibition of either the activity or the production of fungal lytic enzymes occurred in infected tissues of plants challenged by the PG4 avirulent $L$. maculans strain.

Ultrastructural changes of host cells conferred by the introgressed Jlm1 gene or the chromosome B4 in the B. napus genetic background (AACC genome) resembled those shown by cells undergoing the HR in the incompatible interaction $B$. juncea cv. Picra- $L$. maculans PG4. Comparison of cellular changes in water-infiltrated
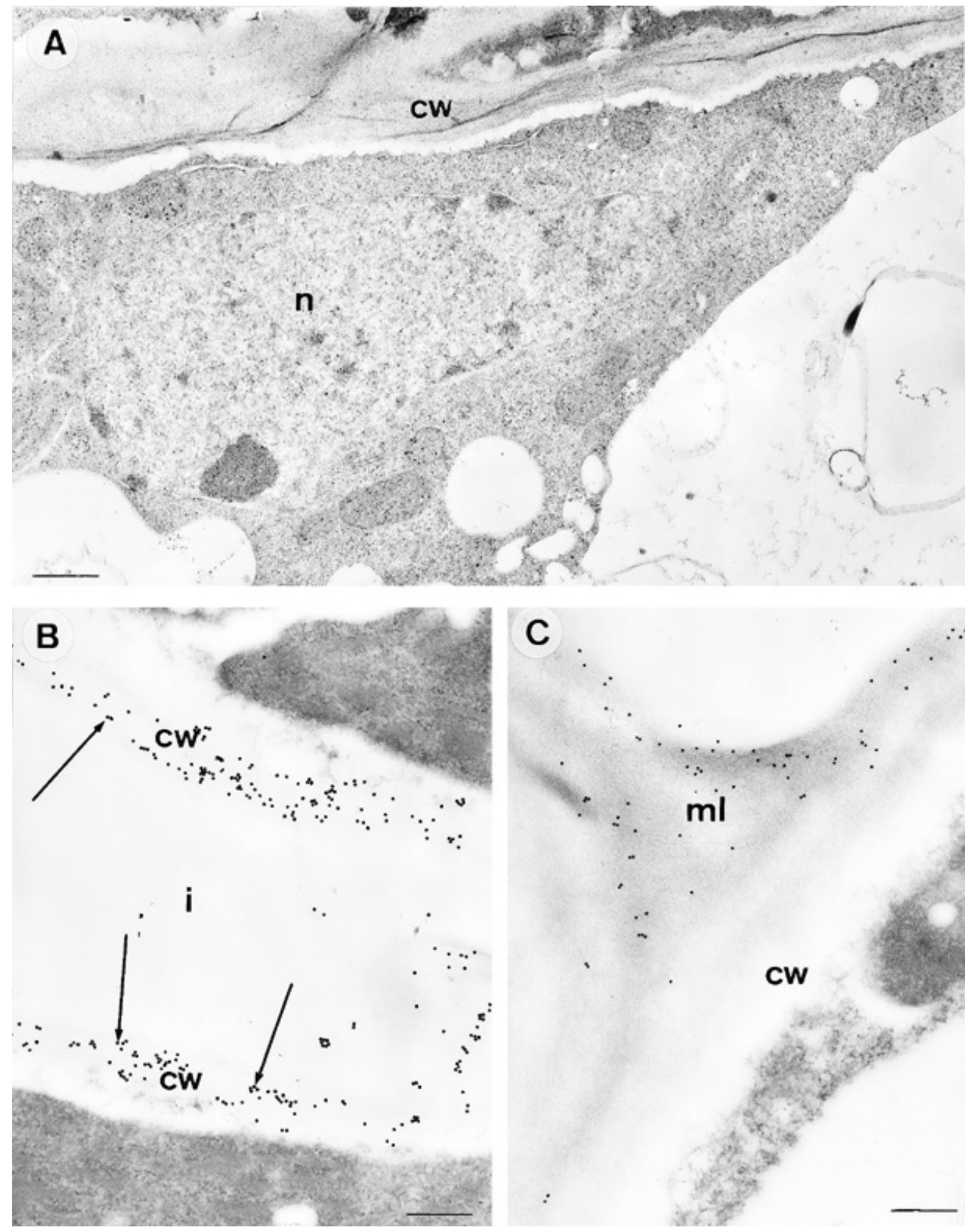
cotyledons with those observed in L. maculans-inoculated ones allowed the distinction between modifications triggered by the wounding process and those induced by the pathogen. Condensation and lobing of nuclei, fragmentation of chromatin, and disruption of nuclear membranes are cytological features that have been reported for plant cell death triggered by avirulent fungi $(5,18,34)$. Invagination of the tonoplast, withdrawal of host plasmalemma, and cytoplasm vacuolation have also been reported during HR cell collapse $(6,14)$. According to our observations, resistance controlled by the Jlm 1 gene or the chromosome B4 in the AACC genome of $B$. napus is characterized by a HR associated with restriction of the fungal development. The positive correlation between the HR and the ultrastructural features of cell death observed in the modified B. napus genotypes indicates that the chromosome B4 and the Jlml gene were able to activate pathways leading to resistance in the B. napus genetic background.
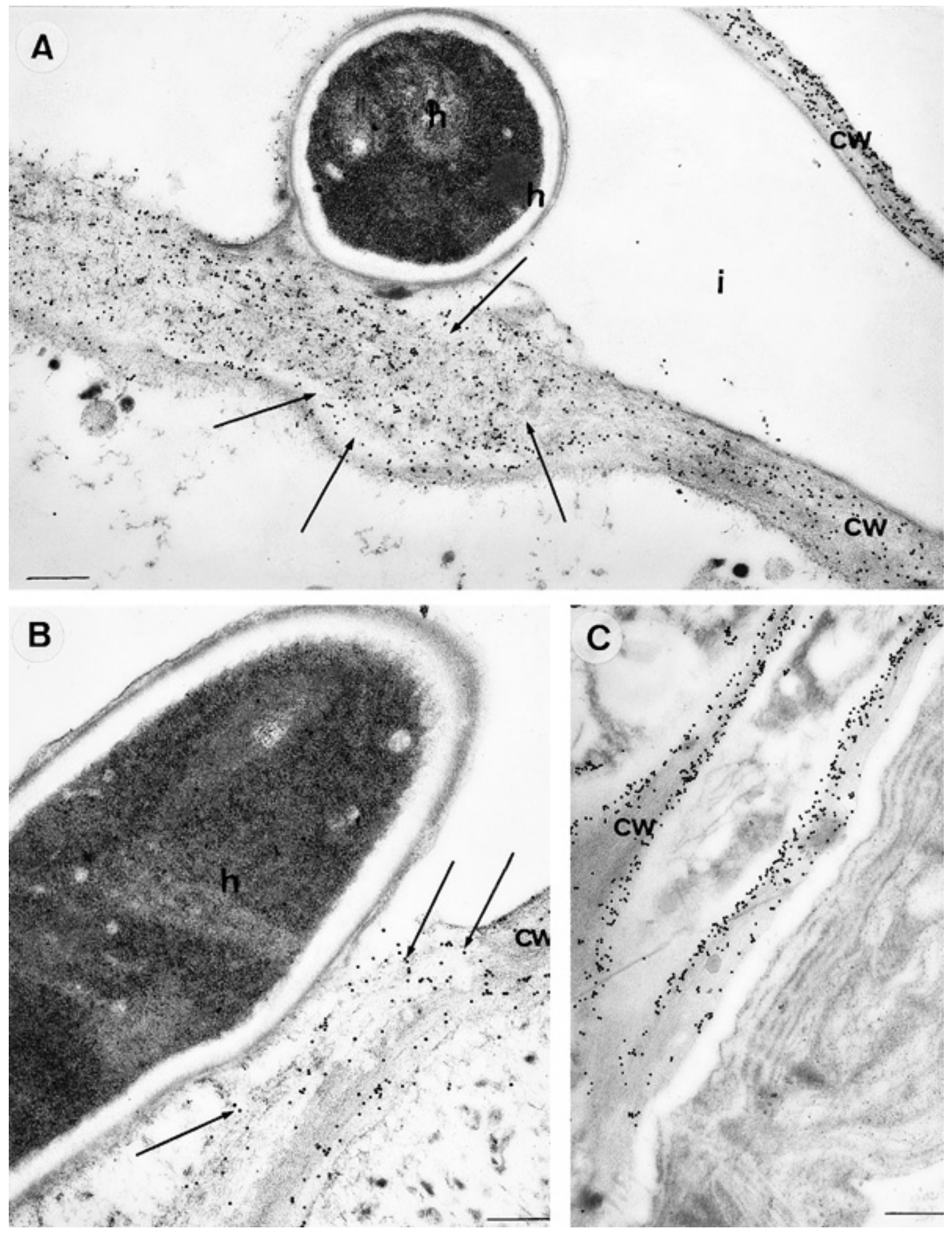

Fig. 5. Transmission electron micrographs of transverse sections of Leptosphaeria maculans-inoculated cotyledons. Glutaraldehyde and osmium tetroxide fixation 12 days after inoculation. Localization of $\beta$-1-4-glucans using an exoglucanase-gold probe. A, In the susceptible Brassica napus cv. Samouraï, swelling of the primary cell wall (cw), in contact with the hypha (h), is associated with areas that show weak labeling (arrows). Very few particles are associated with the fungal cytoplasm. $\mathrm{i}=$ Intercellular space. Bar $=0.7 \mu \mathrm{m}$. B, In the susceptible B. napus cv. Darmor, disruption of the cell wall (cw) close to the hypha (h) displays labeled fragments (arrows). $\mathrm{Bar}=0.3 \mu \mathrm{m}$. C, Walls of cells (cw) in the resistant B. napus-B. nigra addition LA4+ line show an even distribution of gold particles. Bar $=0.3 \mu \mathrm{m}$. 
Three defense reactions were identified microscopically in cotyledons challenged by L. maculans in compatible and incompatible interactions: wall appositions, papillae, and vessel plugging. These are nonspecific responses that are not based on gene-for-gene interactions (23), since they were observed during the infection process in the susceptible B. napus cvs. Samouraï and Darmor. Only detected in zone A in the water controls, we can assume that those responses were triggered by the infection process in the tested genotypes. Wall appositions represent a nonspecific response to cell injury, possibly functioning as part of a mechanism restricting the effects of injury to host cells (29). Similarly, formation of papillae is a common event described in multiple compatible and incompatible interactions $(10,12,37)$, since this process is likely involved in the reinforcement of barriers to lateral fungal spread. Occlusion of vessels has also been reported to usually be associated with colonization of xylem elements by vascular pathogens in many plants species $(3,25)$. Vessel plugging is believed to slow down the active movement of microbes or spore transportation, including L. maculans (30), within the xylem $(22,28,35)$, which is the way $L$. maculans reaches the stem collar (15).
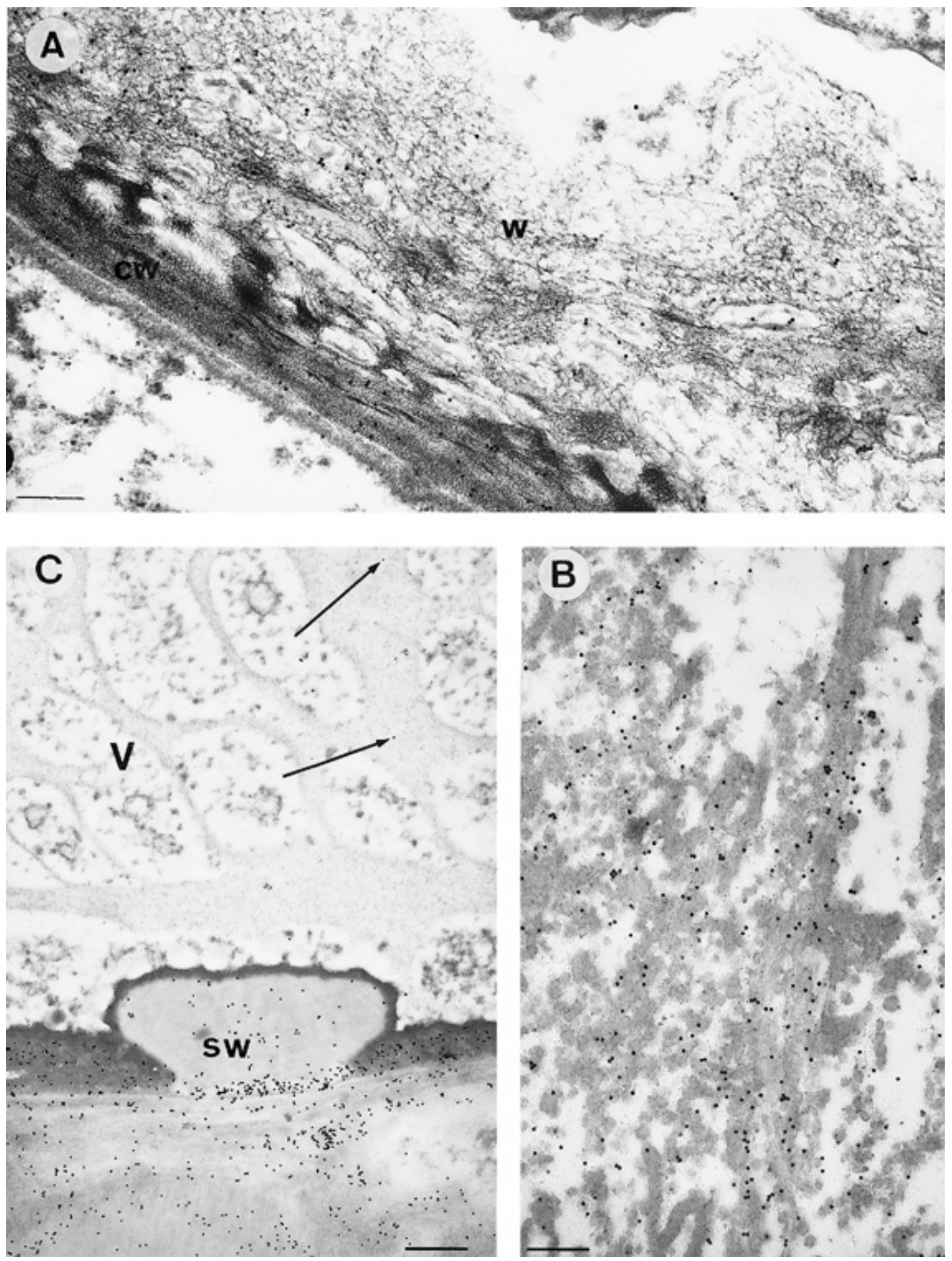

Fig. 6. Transmission electron micrographs of transverse sections of Leptosphaeria maculans-inoculated cotyledons. Glutaraldehyde and osmium tetroxide fixation. Localization of $\beta-1-4$-glucans using an exoglucanase-gold probe 12 days after inoculation. A, Few gold particles are associated with the primary cell wall (cw) and wall appositions (w) in a cotyledon cell of the susceptible Brassica napus cv. Samouraï. Bar $=0.3 \mu \mathrm{m}$. B, In the resistant B. juncea cv. Picra, labeling is intense over the vessel-occluding material. Bar $=0.3 \mu \mathrm{m}$. C, In the MXS line, the labeling (arrows) is no significant over the vessel-accumulating material (arrows) in contrast to the secondary walls (sw). Bar $=0.7 \mu \mathrm{m}$. 
The results of the current cytochemical study provided evidence that wall appositions and papillae contained polysaccharides including cellulose, callose, and pectin, and that material obstructing xylem vessels contains pectic-like molecules and cellulose. The presence of electron-dense bodies within these newly formed structures indicates that compounds other than polysaccharides were deposited sequentially at these sites. The opacity of this material probably is caused by an interaction with osmium tetroxide, suggesting the presence of phenolics, although no autofluorescence under UV illumination was detected within the inoculated host cell structures.

While no difference was seen in frequency and timing of vessel obstruction between the MXS resistant line and the susceptible cv. Samouraï, more extensive wall appositions and papillae were observed in the resistant line. Introgression of the B. juncea JlmI gene in the $B$. napus AACC genome induced a phenotype that was associated with enhanced formation of structural barriers. As compared with the resistant B. juncea cv. Picra, from which the JlmI
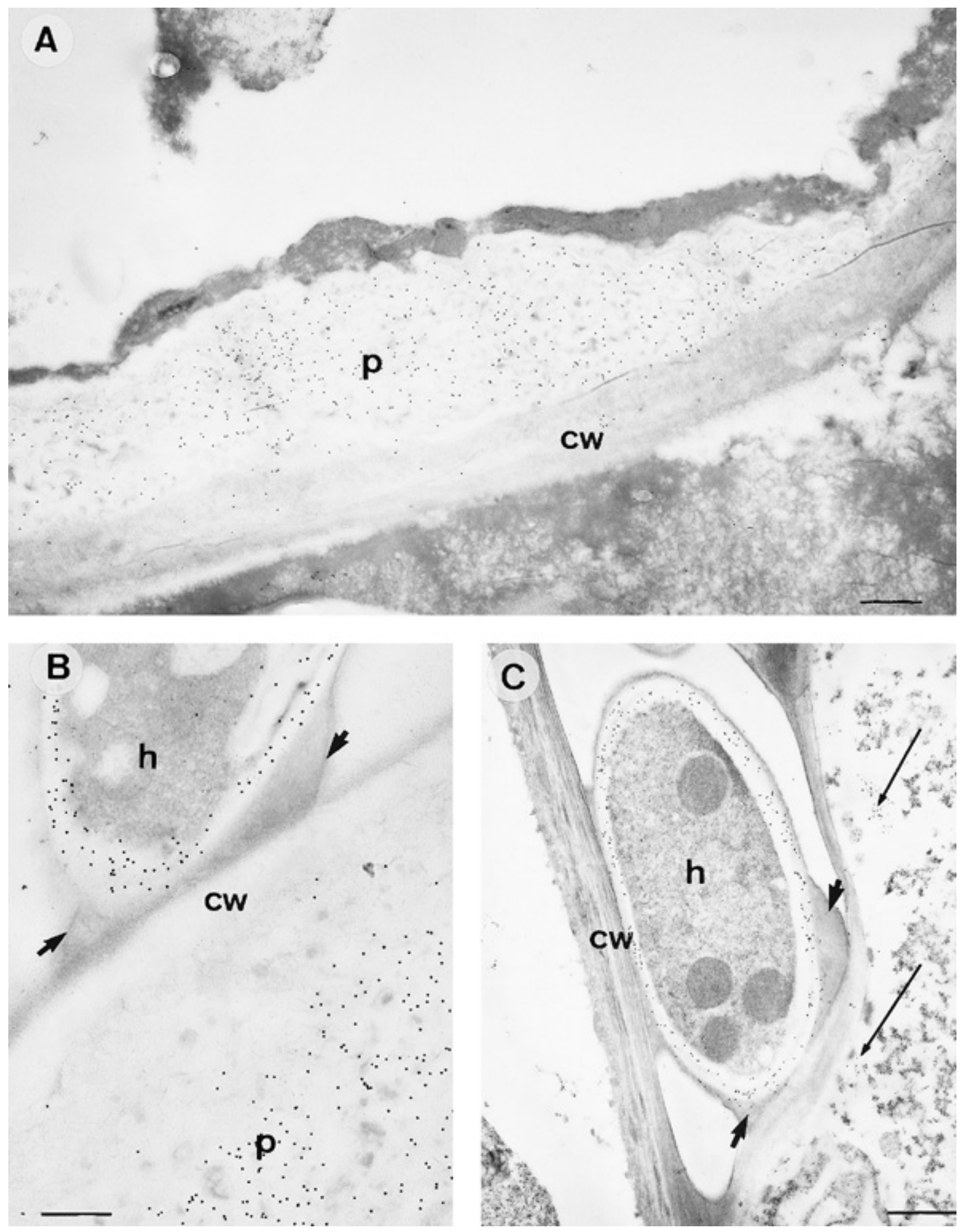

Fig. 7. Transmission electron micrographs of transverse sections of Leptosphaeria maculans-inoculated cotyledons. Glutaraldehyde and osmium tetroxide fixation. Localization of $\beta$-1,3-glucans using polyclonal antibody anti- $\beta$-1,3-glucans followed by incubation with GAR-15 secondary antibodies conjugated to gold 12 days after inoculation. A, A regular and dense labeling is seen over a papilla (p) in the susceptible Brassica napus cv. Darmor. Few gold particles are associated with the cell wall (cw). Bar $=0.5 \mu \mathrm{m}$. B and $\mathbf{C}$, In the MXS line, B, papilla (p) and $\mathbf{C}$, wall appositions (arrows) are evenly labeled. Gold particles are associated with the fungal cell wall. The adhering fungal material in contact with the plant cell wall (cw) (arrowhead) is not labeled. $\mathrm{h}=$ Hypha. B and $\mathbf{C}$, Bars $=0.3$ and $0.7 \mu \mathrm{m}$, respectively. 
gene originated, reinforcement of these cell wall barriers occurred later in the MXS line and was correlated with a less effective restriction of pathogen spread. The weaker expression of resistance in the MXS line in comparison to that observed in B. juncea may result from the absence of another resistance gene that was demonstrated to be involved in the control of L. maculans in B. juncea $(27,38)$. According to Keri et al. (20), the two resistance genes may be epistatic in $B$. juncea. This additional resistance gene could be carried by the chromosome B4, which was introgressed in the B. napus-B. nigra LA4+ line.

During the incompatible interaction LA4+-L. maculans, wall appositions, papillae, and vessel obstruction were similar to that observed in the susceptible B. napus cv. Darmor; however, fungal growth was much weaker and restricted to the infection areas. Resistance conferred by the chromosome B4 in the B. napus genetic background was very efficient, although the current microscopic
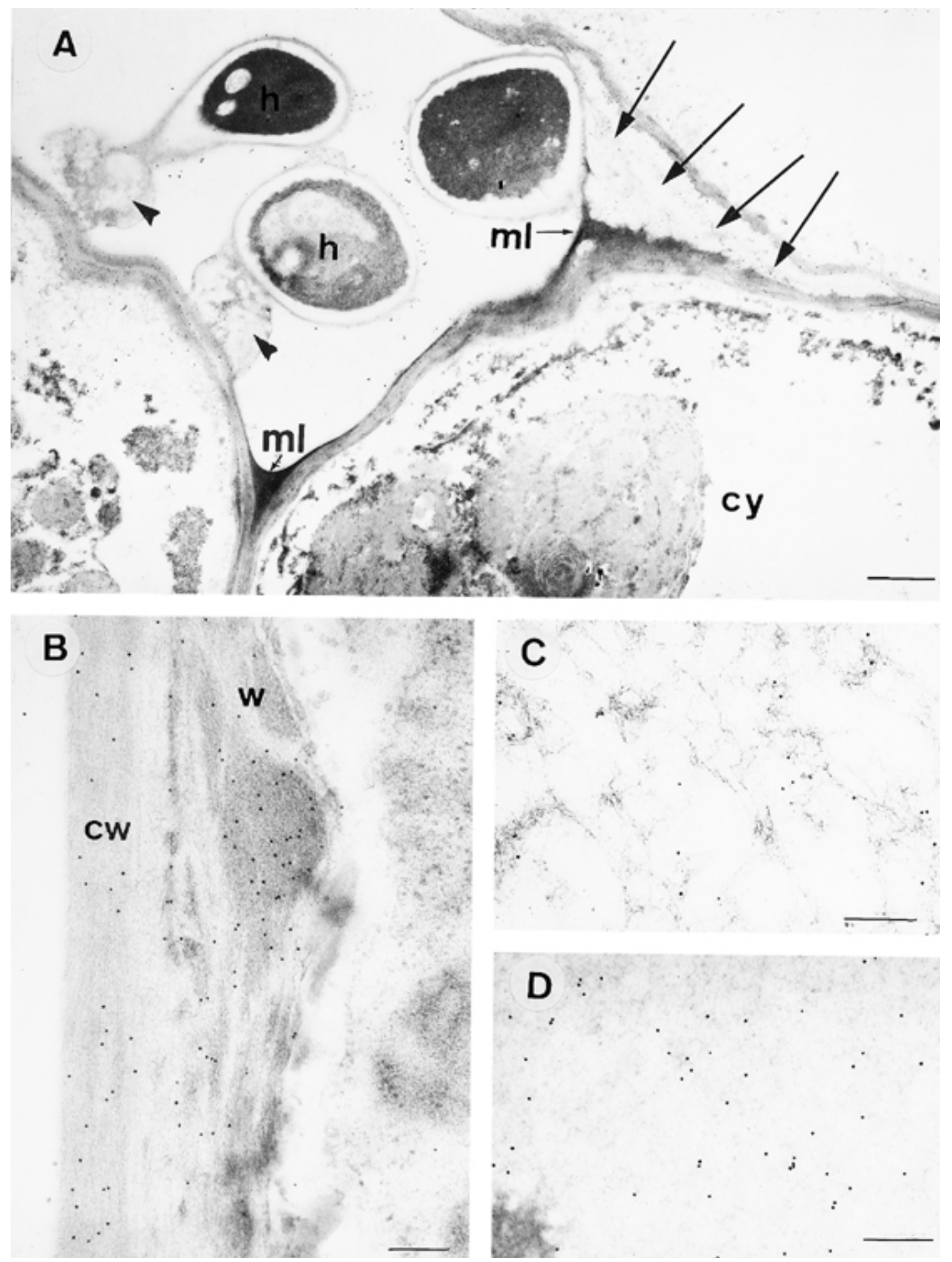

Fig. 8. Transmission electron micrographs of transverse sections of Leptosphaeria maculans-inoculated cotyledons. Glutaraldehyde and osmium tetroxide fixation. Localization of pectin using the JIM 5 monoclonal antibody followed by incubation with GAT-10 secondary antibodies conjugated to gold 12 days after inoculation. A, In the susceptible Brassica napus cv. Samouraï, a regular labeling is observed over the host cell wall and the middle lamella (ml). The fungal adhering material close to the host cell wall does not show any significant labeling (arrowheads). The degraded area of the middle lamella shows a weak labeling (arrows). Notice that the adjacent cells (cy) show pronounced collapse and plasmalemma retraction from the cell walls. $\mathrm{h}=\mathrm{Hypha}$. Bar $=0.8 \mu \mathrm{m}$. B, In the resistant $B$. juncea cv. Picra, the cell wall (cw) and the wall apposition (w) are labeled. Bar $=0.2 \mu \mathrm{m}$. $\mathbf{C}$ and $\mathbf{D}$, Labeling is also present over the material occluding vessels in $\mathbf{C}$, cv. Picra and $\mathbf{D}$, the MXS line. Bars $=0.2 \mu \mathrm{m}$. 
investigation only studied responses that were cytologically detectable. It is likely that the resistance gene carried by the chromosome B4 triggered signaling pathways in B. napus involved in the activation of host defense genes, the expression of which was not assessed here. It is known that the brassilexin phytoalexin accumulates in cotyledons and leaves of $B$. napus-B. juncea interspecific progenies in response to infection by $L$. maculans (31). Accordingly, investigations on phytoalexin accumulation during infection of the LA4+ line by L. maculans would be of interest to assess whether chromosome B4 is able to activate brassilexin or other phytoalexin biosynthesis in the AACC genome background.

In conclusion, the current study demonstrates that the $B$. nigra chromosome B4 and the B. juncea Jlml gene from the B genome both induced a HR in $B$. napus with variable effects on limitation of the pathogen growth. It shows that both origins of B genome resistance trigger mechanisms that lead to ultrastructural features of HR cell death and suggests a possible differential expression of defense genes involved in wall apposition, papillae formation, and vessel plugging, but perhaps not in wall phenolic production. Investigations on the recently created $B$. napus lines that contain both the resistance gene from chromosome B4 and the Jlm 1 gene (A. M. Chèvre, unpublished data) would be of great interest in understanding the key role the B genome may play in mechanisms underlying resistance to $L$. maculans in the $B$. napus AACC genome.

\section{ACKNOWLEDGMENTS}

This work was supported by grants from INRA (France) and CETIOM (France). We are grateful to D. Andrivon, Station de Pathologie Végétale, INRA, Le Rheu, France, and N. Benhamou, University Laval, Quebec, Canada, for the critically reading of the manuscript.

\section{LITERATURE CITED}

1. Annis, S. L., and Goodwin, P. H. 1996. Comparison of cell wall-degrading enzymes produced by highly and weakly virulent isolates of Leptosphaeria maculans in culture. Mycol. Res. 151:401-406.

2. Ansan-Melayah, D., Balesdent, M. H., Buée, M., and Rouxel, T. 1995. Genetic characterization of AvrLml, the first avirulence gene of Leptosphaeria maculans. Phytopathology 85:1525-1529.

3. Beckman, C. H. 1987. The Nature of Wilt Diseases of Plants. The American Phytopathological Society, St. Paul, MN.

4. Benhamou, N., Chamberland, H., Ouellette, G. B., and Pauze, F. J. 1987. Ultrastructural localization of $\beta$-(1-4)-D-glucans in two pathogenic fungi and in their host tissues by means of an exoglucanase gold complex. Can. J. Microbiol. 33:405-417.

5. Bennett, M., Gallagher, M., Fagg, J., Bestwick, C. S., Paul, T., Beale, M., and Mansfield, J. W. 1996. The hypersensitive reaction, membrane damage and accumulation of autofluorescent phenolics in lettuce cells challenged by Bremia lactucae. Plant J. 6:851-865.

6. Bestwick, B., Brown, I. R., Mansfield, J. W., Nicole, M., Boher, B., and Essenberg, M. 1998. Bacterial pathogenesis. Pages 539-572 in: Host Reactions. V: Plants. P. Williams, G. Salmond, and J. Ketley, eds. Academic Press, New York.

7. Chen, C. Y., and Howlett, B. J. 1996. Rapid necrosis of guard cells is associated with the arrest of fungal growth in leaves of Indian mustard (Brassica juncea) inoculated with avirulent isolates of Leptosphaeria maculans. Physiol. Mol. Plant Pathol. 48:73-81.

8. Chèvre, A. M., Barret, P., Eber, F., Dupuy, P., Brun, H., Tanguy, X., and Renard, M. 1997. Selection of stable Brassica napus-B. juncea recombinant lines resistant to blackleg (Leptosphaeria maculans). 1. Identification of molecular markers, chromosomal and genomic origin of the introgression. Theor. Appl. Genet. 95:1104-1111.

9. Chèvre, A. M., Eber, F., This, P., Barret, P., Tanguy, X., Brun, H., Delseny, M., and Renard, M. 1996. Characterization of Brassica nigra chromosomes and of blackleg resistance in $B$. napus-B. nigra addition lines. Plant Breed. 115:113-118.

10. Daayf, F., Nicole, M., Boher, B., Pando, A., and Geiger, J. P. 1997. Early vascular defense reactions of cotton roots infected with a defoliating mutant strain of Verticillium dahliae. Eur. J. Plant Pathol. 103:125-136.

11. Easton, C. J., and Rossall, S. 1985. The production of certain cell-wall degrading enzymes by Leptosphaeria maculans in culture and in stem cankers lesions of oilseed rape. Physiol. Plant Pathol. 26:185-197.
12. Ebrahim-Nesbat, F., Bohl, S., Heitefuss, R., and Appel, K. 1993. Thionin in cell walls and papillae of barley in compatible and incompatible interactions with Erysiphe graminis f.sp. hordei. Physiol. Mol. Plant Pathol. 43:343-352.

13. Ferreira, M. E., Rimmer, S. R., Williams, P. H., and Osborn, T. C. 1995. Mapping loci controlling Brassica napus resistance to Leptosphaeria maculans under different screening conditions. Phytopathology 85:213-217.

14. Goodman, R. N., and Novacky, A. 1994. The Hypersensitive Reaction in Plants to Pathogens: A Resistance Phenomenon. The American Phytopathological Society, St. Paul, MN.

15. Hammond, K. E., and Lewis, B. G. 1987. The establishment of systemic infection in leaves of oilseed rape by Leptosphaeria maculans. Plant Pathol. 36:135-147.

16. Hammond, K. E., Lewis, B. G., and Musa, M. 1985. A systemic pathway in the infection of oilseed rape plants by Leptosphaeria maculans. Plant Pathol. 34:557-565.

17. Hassan, A. K., Schultz, C., Sacristan, M. D., and Wöstemeyer, J. 1991. Biochemical and molecular tools for the differentiation of aggressive and non-aggressive isolates of the oilseed rape pathogen, Phoma lingam. J. Phytopathol. 131:120-136.

18. Heath, M. C. 1998. Apoptosis, programmed cell death and the hypersensitive response. Eur. J. Plant Pathol. 104:117-124.

19. Hill, C. B. 1991. Inheritance of seedling blackleg resistance in canola. Pages 286-291 in: International Rapeseed Congress, Saskatoon, 8th. D. I. McGregor, ed. Saskatoon, Saskatchewan, Canada.

20. Keri, M., van den Berg, C. G. J., McVetty, P. B. E., and Rimmer, S. R. 1997. Inheritance of resistance to Leptosphaeria maculans in Brassica juncea. Phytopathology 87:594-598.

21. Knox, J. P., Linstead, P. J., King, J., Cooper, C., and Roberts, K. 1990. Pectin esterification is spatially regulated both within cell walls and between developing tissues of root apices. Planta 181:512-521.

22. Kpémoua, K., Boher, B., Nicole, M., Calatayud, P., and Geiger, J. P. 1996. Cytochemistry of defense responses in cassava infected by Xanthomonas pv. manihotis. Can. J. Microbiol. 42:1131-1143.

23. Mansfield, J. W., Bennet, M. H. R., Bestwick, C. S., and Woods-Tör, A. 1997. Phenotypic expression of gene-for-gene interaction involving fungal and bacterial pathogens: Variation from recognition to response. Pages 265-291 in: The Gene-for-Gene Relationship in Plant-Parasite Interactions. I. R. Crute, E. B. Holub, and J. J. Burton, eds. CAB International, Wallingford, United Kingdom.

24. Mengistu, A., Rimmer, S. R., Koch, E., and Williams, P. H. 1991. Pathogenicity grouping of isolates of Leptosphaeria maculans on Brassica napus cultivars and their disease reaction profiles on rapid-cycling brassicas. Plant Dis. 75:1279-1282.

25. Mueller, W. C., and Morgham, A. T. 1992. Ultrastructure of the vascular responses of cotton to Verticillium dahliae. Can. J. Bot. 71:32-36.

26. Pilet, M. L., Delourme, R., Foisset, N., and Renard, M. 1997. Identification of loci contributing to quantitative field resistance to blackleg disease, causal agent Leptosphaeria maculans (Desm.) Ces. Et de Not., in winter rapeseed (Brassica napus L.). Theor. Appl. Genet. 96:23-30.

27. Rimmer, S. R., and Van den Berg, C. G. J. 1992. Resistance of oilseed Brassica spp. to blackleg caused by Leptosphaeria maculans. Can. J. Plant Pathol. 14:56-66.

28. Rioux, D., Nicole, M., Simard, M., and Ouellette, G. B. 1998. Immunocytochemical evidence that secretion of pectin occurs during gel (gum) and tylosis formation in trees. Phytopathology 88:494-505.

29. Robb, J., Lee, S. W., Mohan, R., and Kolattudy, P. E. 1991. Chemical characterization of stress-induced vascular coating in tomato. Plant Physiol. 97:528-536.

30. Roussel, S., Nicole, M., Lopez, F., Geiger, J. P., Renard, M., and Brun, H. 1999. Leptosphaeria maculans and cryptogein induce similar vascular responses in tissues undergoing the hypersensitive reaction in Brassica napus. Plant Sci. 144:17-28.

31. Rouxel, T., Renard, M., Kollmann, A., and Bousquet, J. F. 1990. Brassilexin accumulation and resistance to Leptosphaeria maculans in Brassica spp. and progeny of an interspecific cross $B$. juncea $\times B$. napus. Euphytica 46:175-181.

32. Rouxel, T., Sarniguet, A., Kollmann, A., and Bousquet, J. F. 1989. Accumulation of a phytoalexin in Brassica spp. in relation to a hypersensitive reaction to Leptosphaeria maculans. Physiol. Mol. Plant Pathol. 34: 507-517

33. Roy, N. N. 1984. Interspecific transfer of Brassica juncea-type high blackleg resistance to Brassica napus. Euphytica 33:295-303.

34. Schmelzer, E., Naton, B., Freytag, S., Rouhara, I., Küster, B., and Hahlbrock, K. 1995. Infection-induced rapid cell death in plants: A means of efficient pathogen defense. Can. J. Bot. 73:426-434.

35. Shi, J., Mueller, W. C., and Beckman, C. H. 1992. Vessels occlusion and secretory activities of vessel contact cells in resistant or susceptible cotton plants infected with Fusarium oxysporum f.sp. vasinfectum. Physiol. 
Mol. Plant Pathol. 40:133-147.

36. Somda, I., Renard, M., and Brun, H. 1996. Morphology, pathogenicity and isozyme variation amongst French isolates of Leptosphaeria maculans recovered from Brassica juncea cv. Picra. Plant Pathol. 45:10901098.

37. Stanghellini, M. E., Rasmussen, S. L., and Vandenmark, G. J. 1993. Relationship of callose deposition to resistance of lettuce to Plasmopara lactucae-radicis. Phytopathology 83:1498-1501.

38. Struss, D., Quiros, C. F., Plieske, J., and Röbbelen, G. 1996. Construction of Brassica B genome synteny groups based on chromosomes extracted from three different sources by phenotypic, isozyme and molecular markers. Theor. Appl. Genet. 93:1026-1032.

39. Williams, P. H., and Delwiche, P. A. 1979. Screening for resistance to blackleg of crucifers in the seedling stage. Cruciferae Newsl. 4:24. 